\title{
Industry Payments Are Prevalent and Contagious in Subspecialty Medical Education
}

J Gen Intern Med 36(10):3257-60

DOI: $10.1007 / \mathrm{s} 11606-021-06612-\mathrm{Z}$

(C) Society of General Internal Medicine 2021

\section{INTRODUCTION}

Clinical providers may not feel that industry payments impact their practice, but a growing body of evidence demonstrates that such conflicts of interests alter practice behaviors in multiple settings. ${ }^{1,2}$ Even a single meal has been associated with increased prescribing of the promoted brand name medication. ${ }^{3}$ Medical trainees may represent a vulnerable population to the reception and effects of industry relationships as they have limited experience in managing conflicts of interest and have great practice longevity compared to physicians already in practice.

Major medical societies and governing bodies including the Association of American Medical Colleges, Accreditation Council for Graduate Medical Education, and National Academy of Medicine are strong proponents of removing any actual or perceived conflicts of interest in medical education which are expounded in their policy statements. ${ }^{4,5}$ Over the past decade, academic medical institutions have also created their own conflict of interest policies to prohibit industry interactions among medical students and clinical trainees in order to preserve the integrity of medical education. To date, industry payments to medical trainees including their prevalence have not been objectively characterized and the actual adherence of training programs to national and institutional policies have yet to be examined. In addition, factors that contribute to physician-industry relationships such as personal interactions have not been elucidated despite the increased scrutiny of financial conflicts of interest.

\section{METHODS}

The passage of the Physician Payments Sunshine Act in 2010 mandated the reporting of all payments or transfers of value from manufacturers of drugs, devices, biologicals, or medical supplies to physicians and teaching hospitals. This data is continuously tracked by the Centers for Medicare and Medicaid Services and is publicly accessible on the Open Payments

Received June 26, 2020

Accepted January 7, 2021

Published online January 27, 2021 database which is updated yearly. ${ }^{6}$ Using this unique resource, we assessed payments to physicians in fellowship, the terminal subspecialty training program in the USA, and its association with demographics and program characteristics.

Open Payments data were used to perform a cross-sectional study of industry payments to internal medicine fellows across 9 subspecialties. Fellows were assessed because students and residents are excluded from Open Payments. Fellows and program directors (PDs) were abstracted from institutional websites of the 100 largest internal medicine residencies (by total residents) because they frequently harbor multiple subspecialty fellowships. To provide a comparative analysis across subspecialties with either 2 or 3 years of required training, we assessed all fellows that matriculated in the 2016 academic year and examined Open Payments data from July 1, 2016 to July 1, 2018 (accessed on August 1, 2019, after the release of 2018 data). As only two fellows received research payments, and none received ownership payments, we assessed general payments to fellows. As PD tenure could not be determined, PD payment data were analyzed from 2013 (first year that Open Payments data were available) to 2018.

\section{RESULTS}

Institutional websites yielded 1953 fellows across 479 programs, accounting for $58 \%$ of fellows matriculating into 9 subspecialties in 2016. In the first 2 years of subspecialty education, $54 \%$ of fellows received industry payments from 233 companies valuing $\$ 1,031,627.94$, with $39.1 \%, 18.5 \%$, $18.4 \%, 12.2 \%, 7.0 \%$, and $4.8 \%$ paid towards food, nonconsulting services, travel, grants, consulting fees, and education, honoraria, and gifts, respectively (Table 1). Among fellows receiving industry payments, median payments perfellow ranged from \$136.33 (IQR \$44.26-501.57) for infectious disease to $\$ 536.37$ (IQR \$188.58-1814.74) for cardiology. Of 479 PDs, $86.6 \%$ received payments between 2013 and 2018 valuing $\$ 14,439,911.39$, with $76.4 \%, 1.7 \%$, and $21.9 \%$ paid towards non-research, ownership, and research payments, respectively. Among PDs receiving industry payments, the median payment per-PD was \$1989.66 (IQR \$171.20$15,881.47)$.

Multilevel binary logistic regression to account for fellows nested in programs within institutions was used to identify predictors of whether a fellow would receive industry payments (Table 2). Male sex (adjusted odds ratio [OR], 1.31; 


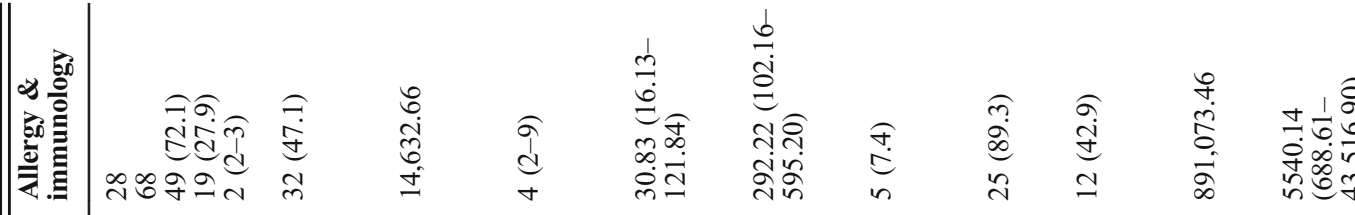

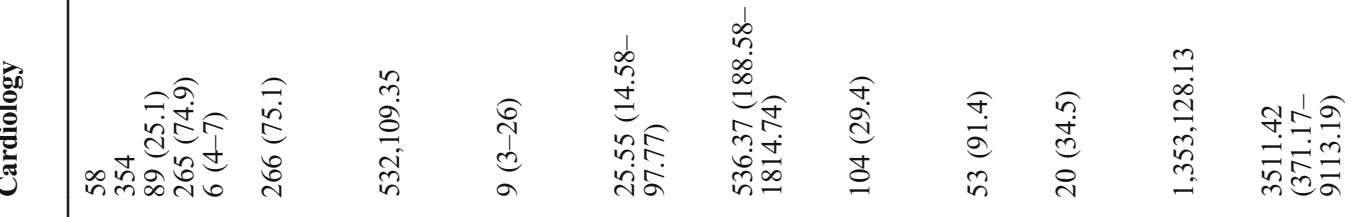

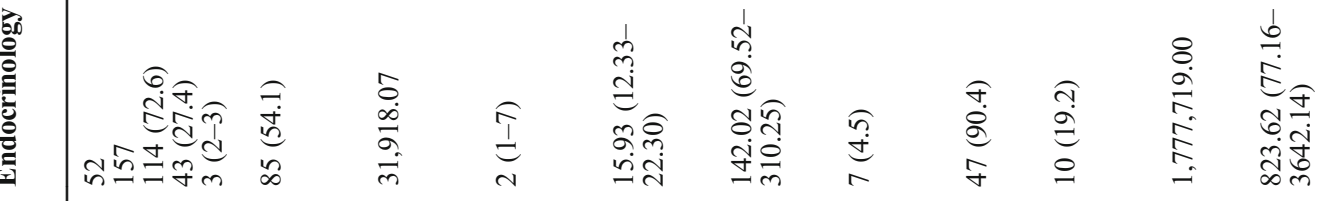

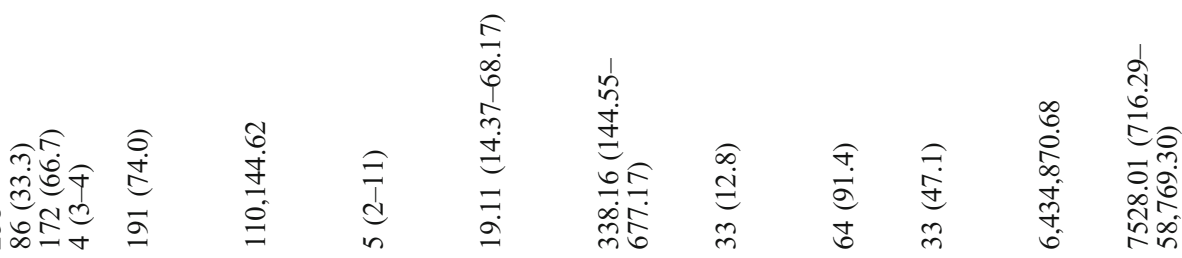

कิก

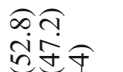
츠웡 in $\underset{\infty}{+\infty}$

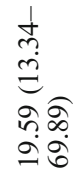

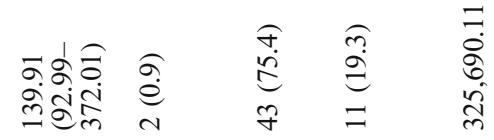

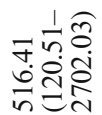

$\frac{1}{60}$

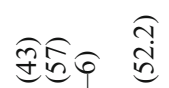

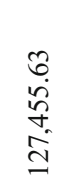
$\underset{\substack{d \\ \stackrel{d}{d}}}{\stackrel{1}{d}}$

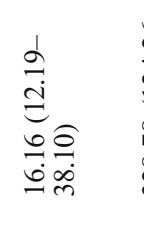

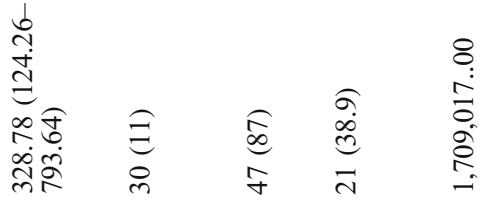

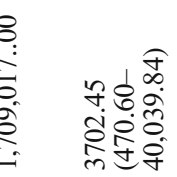

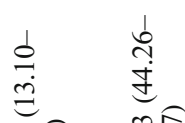

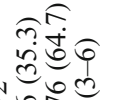
б종ํํ m

2
$\substack{0 \\ 1 \\ \infty}$
$\infty$

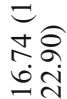

mูin

$\stackrel{\overbrace{}}{\check{2}}$

\begin{tabular}{ll}
$\underset{\sigma}{\sigma}$ & \multirow{\sigma}{0}{} \\
$\dot{\infty}$ & $\stackrel{0}{0}$
\end{tabular}

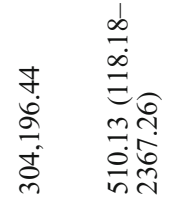

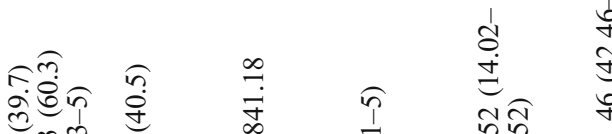

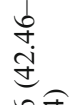

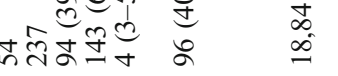

$\stackrel{n}{\stackrel{n}{\sim}}$

กุ๊

$\underset{n}{\overbrace{}}$

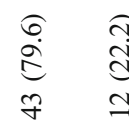

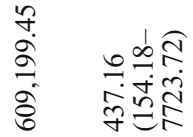

$\infty \quad 8$

तิळ0 ก)

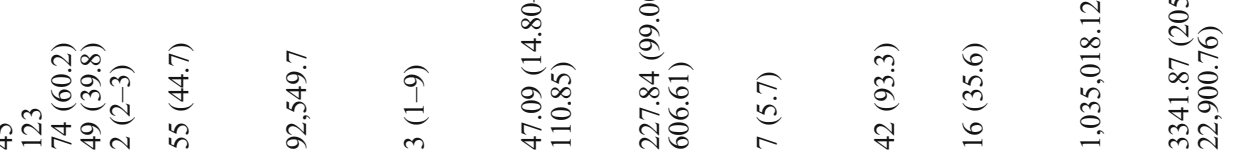

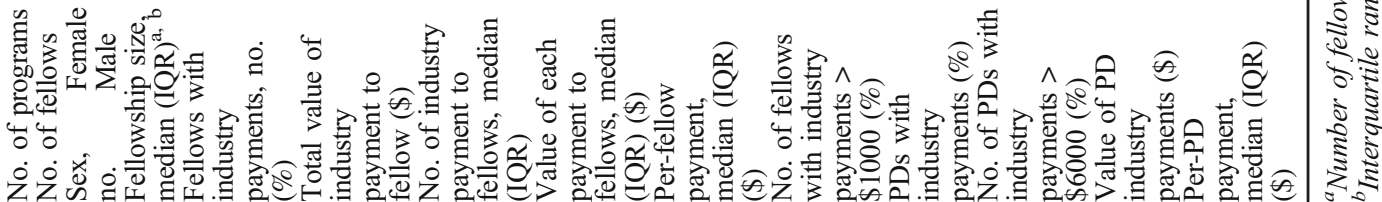


Table 2 Multilevel Binary Logistic Regression Analysis of Any and High-Value Industry Payments to Fellows

\begin{tabular}{|c|c|c|c|c|}
\hline & \multicolumn{2}{|c|}{$\begin{array}{l}\text { Any industry } \\
\text { payment }\end{array}$} & \multicolumn{2}{|c|}{$\begin{array}{l}\text { Industry payment } \\
>\$ 1000\end{array}$} \\
\hline & $\begin{array}{l}\text { Adjusted } \\
\text { OR }\end{array}$ & $\begin{array}{l}P \\
\text { value }\end{array}$ & $\begin{array}{l}\text { Adjusted } \\
\text { OR }\end{array}$ & $\begin{array}{l}P \\
\text { value }\end{array}$ \\
\hline \multicolumn{5}{|l|}{ Sex } \\
\hline Female & $\begin{array}{l}1 \\
\text { [Reference] }\end{array}$ & & $\begin{array}{l}1 \\
\text { [Reference] }\end{array}$ & \\
\hline Male & $\begin{array}{l}1.31(1.06- \\
1.63)\end{array}$ & 0.01 & $\begin{array}{l}1.49(1.04- \\
2.14)\end{array}$ & 0.03 \\
\hline \multicolumn{5}{|l|}{ Program size } \\
\hline 1 to 4 fellows & $\begin{array}{l}1 \\
\text { [Reference] }\end{array}$ & & $\begin{array}{l}1 \\
\text { [Reference] }\end{array}$ & \\
\hline 5 or more fellows & $\begin{array}{l}0.86(0.66- \\
1.12)\end{array}$ & 0.27 & $\begin{array}{l}0.77(0.51- \\
1.18)\end{array}$ & 0.23 \\
\hline \multicolumn{5}{|c|}{ Industry payments to $\mathrm{PD}$} \\
\hline No & $\begin{array}{l}1 \\
{[\text { Reference] }}\end{array}$ & & $\begin{array}{l}1 \\
{[\text { Reference] }}\end{array}$ & \\
\hline Yes & $\begin{array}{l}2.10(1.50- \\
2.95)\end{array}$ & $<0.001$ & $\begin{array}{l}3.38(1.50- \\
7.59)\end{array}$ & $<0.001$ \\
\hline \multicolumn{5}{|c|}{ Top research internal medicine program ${ }^{\mathrm{a}}$} \\
\hline No & $\begin{array}{l}1 \\
\text { [Reference] }\end{array}$ & & $\begin{array}{l}1 \\
{[\text { Reference }]}\end{array}$ & \\
\hline Yes & $\begin{array}{l}0.48(0.32- \\
0.71)\end{array}$ & $<0.001$ & $\begin{array}{l}1.09(0.57- \\
2.09)\end{array}$ & 0.79 \\
\hline \multicolumn{5}{|c|}{ American Medical Student Association Conflict of Interest Score } \\
\hline $\mathrm{C}$ or lower & $\begin{array}{l}1 \\
\text { [Reference] }\end{array}$ & & $\begin{array}{l}1 \\
{[\text { Reference] }}\end{array}$ & \\
\hline $\mathrm{B}$ & $\begin{array}{l}1.22(0.65- \\
2.31)\end{array}$ & 0.53 & $\begin{array}{l}0.65(0.28- \\
1.49)\end{array}$ & 0.31 \\
\hline A & $\begin{array}{l}0.97(0.49- \\
1.89)\end{array}$ & 0.92 & $\begin{array}{l}0.39(0.15- \\
1.02)\end{array}$ & 0.06 \\
\hline \multicolumn{5}{|l|}{ Specialty } \\
\hline Rheumatology & $\begin{array}{l}1 \\
\text { [Reference] }\end{array}$ & & $\begin{array}{l}1 \\
{[\text { Reference }]}\end{array}$ & \\
\hline $\begin{array}{c}\text { Allergy \& } \\
\text { immunology }\end{array}$ & $\begin{array}{l}1.05(0.55- \\
2.03)\end{array}$ & 0.88 & $\begin{array}{l}1.05(0.29- \\
3.72)\end{array}$ & 0.94 \\
\hline Cardiology & $\begin{array}{l}3.63(2.17- \\
6.08)\end{array}$ & $<0.001$ & $\begin{array}{l}6.44(2.61- \\
15.87)\end{array}$ & $<0.001$ \\
\hline Endocrinology & $\begin{array}{l}1.34(0.79- \\
2.26)\end{array}$ & 0.28 & $\begin{array}{l}0.66(0.21- \\
2.05)\end{array}$ & 0.48 \\
\hline Gastroenterology & $\begin{array}{l}3.40(2.05- \\
5.64)\end{array}$ & $<0.001$ & $\begin{array}{l}1.79(0.73- \\
4.42)\end{array}$ & 0.20 \\
\hline Infectious disease & $\begin{array}{l}0.48(0.28- \\
0.81)\end{array}$ & 0.01 & $\begin{array}{l}0.16(0.03- \\
0.81)\end{array}$ & 0.03 \\
\hline $\begin{array}{l}\text { Hematology \& } \\
\text { oncology }\end{array}$ & $\begin{array}{l}1.49(0.91- \\
2.46)\end{array}$ & 0.12 & $\begin{array}{l}2.19(0.86- \\
5.56)\end{array}$ & 0.10 \\
\hline $\begin{array}{l}\text { Pulmonology \& } \\
\text { critical care }\end{array}$ & $\begin{array}{l}1.03(0.63- \\
1.69)\end{array}$ & 0.89 & $\begin{array}{l}1.43(0.55- \\
3.69)\end{array}$ & 0.46 \\
\hline Nephrology & $\begin{array}{l}0.89(0.54 \\
1.46)\end{array}$ & 0.63 & $\begin{array}{l}0.24(0.06- \\
0.99)\end{array}$ & .05 \\
\hline
\end{tabular}

${ }^{a}$ Top research internal medicine residency programs are defined as the top 15 ranked institutions by the Doximity research output metric which is determined by the h-index and number of grants awarded to recent fellow alumni

95\% CI, 1.06-1.63), cardiology specialization (adjusted OR, 3.63; 95\% CI, 2.17-6.08), and gastroenterology specialization (adjusted OR, 3.40; 95\% CI, 2.05-5.64) were associated with industry payments to fellows. Infectious disease specialization (adjusted OR, 0.48; 95\% CI, 0.28-0.81) and training at a top ranked research internal medicine program by Doximity (adjusted OR, 0.48; 95\% CI, 0.32-0.71) were negatively associated with industry payments. Industry payments to a PD were independently associated with fellow industry payments (adjusted OR, 2.10; 95\% CI, 1.50-2.95). The American Medical Student Association Conflict of Interest Scorecard evaluates the strength and transparency of institution policies with letter grades, but was not significantly associated with fellow payments. ${ }^{6}$ A sensitivity analysis in which the regression was repeated with increasing cutoffs of PD industry payment values demonstrated that payment values beyond the median payment per-PD remained predictive of fellow industry payments.

Analysis of fellows that received industry payments greater than the mean value of fellow industry payments (\$1000) demonstrated that male sex, PD industry payments, and cardiology specialization were associated with high-value fellow industry payments (Table 2).

\section{DISCUSSION}

Industry interactions can influence physicians and medical trainees resulting in more industry-friendly attitudes and increased use of non-evidence-based and brand drug prescriptions. $^{7-9}$ This is perhaps expected given that periods of clinical training including residency and fellowship provide formative experiences. Thus, medical trainees may represent a vulnerable population to the reception and effects of industry relationships as they have limited experience in managing conflicts of interest and have great practice longevity compared to physicians already in practice.

This study demonstrates that industry payments are prevalent among subspecialty fellows and PDs. Male sex, specialties, and a supportive research environment may be determinants of fellow industry payments. Notably, program director industry payments were predictive of any and high-value fellow industry payments, but were predominantly not related to research and may thus be dispensable. Importantly, PDs are primarily responsible for the oversight and development of training programs, as well as adherence to accreditation requirements and institutional policies. PDs also have a prominent role in the teaching and mentorship of fellows, demonstrating how PDs have frequent interactions or maintain close relationships with fellows. The finding that conflicts of interests may spread through such organization and social ties has implications on the design and monitoring of financial relationships with industry in fellowship programs. For instance, if policies are to eliminate industry payments to fellows entirely, our results suggest that ensuring participation of all members including its leadership is likely necessary.

Limitations of this study include a focus on large medical centers and that not all fellows could be ascertained from public sources. In addition, because the exact period of PD appointments could not be identified, payments to PDs may not have been solely given during their tenure. Further research is needed to clarify the role of industry in medical education and how fellow industry payments affect future behaviors. Nonetheless, because industry payments are linked to provider behaviors that impact patient care, medical educational programs should re-evaluate conflict of interest policies to all of its members. 
Waqas Haque, MPhil ${ }^{1}$

Magdalena Espinoza, $\mathrm{MD}^{2}$

David Hsiehchen, $M D^{3}$

${ }^{1}$ Johns Hopkins School of Public Health, Johns Hopkins University,

Baltimore, MD, USA

${ }^{2}$ Division of Digestive and Liver Diseases, Department of Internal Medicine, University of Texas Southwestern Medical Center,

Dallas, TX, USA

${ }^{3}$ Division of Hematology and Oncology, Department of Internal Medicine, University of Texas

Southwestern Medical Center,

Dallas, TX 75235, USA

Corresponding Author: David Hsiehchen, MD; Division of Hematology and Oncology, Department of Internal Medicine, University of Texas Southwestern Medical Center, Dallas, TX 75235, USA (e-mail: gbtwnow@gmail.com).

\section{Compliance with Ethical Standards:}

Conflict of Interest: The authors declare that they do not have a conflict of interest.

\section{REFERENCES}

1. Hartung DM, Johnston K, Cohen DM, Nguyen T, Deodhar A, Bourdette DN. Industry Payments to Physician Specialists Who Prescribe Repository Corticotropin. JAMA Netw Open 2018;1(2):e180482.
2. Mitchell AP, Winn AN, Lund JL, Dusetzina SB. Evaluating the Strength of the Association Between Industry Payments and Prescribing Practices in Oncology. Oncologist. 2019;24(5):632-639.

3. DeJong C, Aguilar T, Tseng CW, Lin GA, Boscardin WJ, Dudley RA. Pharmaceutical Industry-Sponsored Meals and Physician Prescribing Patterns for Medicare Beneficiaries. JAMA Intern Med 2016;176(8):11141122 .

4. Accreditation Council for Graduate Medical Education. Principles to Guide the Relationship between Graduate Medical Education, Industry, and Other Funding Sources for Programs and Sponsoring Institutions Accredited by the ACGME. 2011. https://www.acgme.org/Portals/0/ PFAssets/PublicationsPapers/pp_GMEGuide.pdf.

5. Lo B, Field MJ, Institute of Medicine (U.S.). Committee on Conflict of Interest in Medical Research Education and Practice., National Academies Press (U.S.). Conflict of interest in medical research, education, and practice. Washington, DC: National Academies Press; 2009.

6. Services CfMM. Open Payments. 2020; https://openpaymentsdata.cms. gov/. Accessed 8/1/2019.

7. McCormick BB, Tomlinson G, Brill-Edwards P, Detsky AS. Effect of restricting contact between pharmaceutical company representatives and internal medicine residents on posttraining attitudes and behavior. JAMA. 2001;286(16): 1994-1999.

8. Zipkin DA, Steinman MA. Interactions between pharmaceutical representatives and doctors in training. A thematic review. J Gen Intern Med 2005;20(8):777-786.

9. Fickweiler F, Fickweiler W, Urbach E. Interactions between physicians and the pharmaceutical industry generally and sales representatives specifically and their association with physicians' attitudes and prescribing habits: a systematic review. BMJ Open 2017;7(9):e016408.

Publisher's Note: Springer Nature remains neutral with regard to jurisdictional claims in published maps and institutional affiliations. 